\title{
Flexible bronchoscopy as the first-choice method of removing foreign bodies from the airways of adults****
}

\author{
Broncoscopia flexível como primeira opção para a remoção \\ de corpo estranho das vias aéreas em adultos
}

\section{Ascedio José Rodrigues, Eduardo Quintino Oliveira, Paulo Rogério Scordamaglio, Marcelo Gervilla Gregório, Márcia Jacomelli, Viviane Rossi Figueiredo}

\begin{abstract}
Objective: To determine the success rate of flexible bronchoscopy as the first-choice method of removing foreign bodies from the airways of adults. Methods: This was a retrospective study of all adult patients (over 18 years of age) with foreign body aspiration submitted to bronchoscopy between January of 2009 and January of 2011 at the University of São Paulo School of Medicine Hospital das Clínicas, located in São Paulo, Brazil. Results: The study sample comprised 40 adult patients, with a mean age of 52 years (range, 18-88 years). The median time of permanence of the foreign body in the airway was 15 days (range, $12 \mathrm{~h}$ to 10 years). All of the patients first underwent diagnostic flexible bronchoscopy. Foreign bodies were successfully removed with flexible bronchoscopy in $33(82.5 \%)$ of the patients. In 1 patient, a metal object lodged in the distal bronchial tree required the use of fluoroscopy. Six patients (15\%) required rigid bronchoscopy due to tracheal foreign bodyinduced dyspnea, in 2, and because the foreign body was too large for the flexible forceps, in 4. Bronchoscopy failed in 1 patient, who therefore required surgical bronchotomy. Conclusions: Although rigid bronchoscopy is considered the gold standard for the removal of foreign bodies from the airways, our experience showed that flexible bronchoscopy can be safely and effectively used in the diagnosis and treatment of stable adult patients.
\end{abstract}

Keywords: Bronchoscopy; Foreign bodies; Airway obstruction; Airway management.

\section{Resumo}

Objetivo: Determinar a taxa de sucesso da broncoscopia flexível como primeira opção na remoção de corpos estranhos das vias aéreas em adultos. Métodos: Estudo retrospectivo de todos os pacientes adultos (acima de 18 anos) com aspiração de corpo estranho submetidos à broncoscopia no Hospital das Clínicas, Faculdade de Medicina da Universidade de São Paulo, em São Paulo (SP). Resultados: A amostra foi constituída por 40 pacientes adultos, com média de idade de 52 anos (variação: 18-88 anos). A mediana do tempo de permanência do corpo estranho na via aérea foi de 15 dias (variação: $12 \mathrm{~h}$ a 10 anos). Todos os pacientes foram submetidos primeiramente a broncoscopia flexível diagnóstica. A retirada do corpo estranho por meio de broncoscopia flexível foi bem-sucedida em 33 dos pacientes (82,5\%). Em 1 paciente, um objeto metálico alojado na árvore brônquica distal requereu o uso de fluoroscopia. Seis pacientes (15\%) foram submetidos à broncoscopia rígida devido a dispneia induzida por corpo estranho traqueal, em 2, e porque o corpo estranho era muito grande para as pinças flexíveis, em 4. A broncoscopia falhou em apenas 1 paciente, que portanto necessitou de broncotomia cirúrgica. Conclusões: Embora a broncoscopia rígida seja considerada o padrão ouro na remoção de corpos estranhos na via aérea, nossa experiência mostrou que a broncoscopia flexível pode ser utilizada segura e eficientemente no diagnóstico e tratamento de pacientes adultos estáveis.

Descritores: Broncoscopia; Corpos estranhos; Obstrução das vias respiratórias; Manuseio das vias aéreas.

\footnotetext{
* Study carried out in the Department of Respiratory Endoscopy, Instituto do Coração - InCor, Heart Institute - University of São Paulo School of Medicine Hospital das Clínicas, São Paulo, Brazil.

Correspondence to: Ascedio Jose Rodrigues. Serviço de Endoscopia Respiratória HC-FMUSP, Prédio dos Ambulatórios, $6^{\circ}$ andar, bloco 3, Avenida Dr. Enéas de Carvalho Aguiar, 255, Cerqueira César. CEP 05017-000, São Paulo, SP, Brasil.

Tel. 5511 2661-5612. E-mail: ascedio@gmail.com

Financial support: None.

Submitted: 22 November 2011. Accepted, after review: 13 February 2012.

** A versão completa em português deste artigo está disponível em www.jornaldepneumologia.com.br
} 


\section{Introduction}

Foreign body (FB) aspiration is a serious and potentially fatal situation. ${ }^{(1-3)}$ The severity of the symptoms depends on the degree of airway obstruction. In the event of total or subtotal obstruction (of the larynx or trachea, in particular), asphyxia can rapidly lead to death. Lesser degrees of obstruction or FB obstruction of the distal bronchial tree generally produce milder symptoms.

Although FB aspiration can occur at any stage in life, it is far more common in children. In adults, FB aspiration is uncommon and is mostly related to accidental aspiration of working tools (paper clips, tacks, or nails) and bone fragments, as well as occurring during unconsciousness (trauma, general anesthesia, sedation, intoxication, seizures, and neurological disorders).(1)

The diagnosis of FB aspiration is essential, given that delayed recognition and treatment of FB aspiration can result in permanent side effects or fatal damage.

Bronchoscopy is the first-choice method for the removal of airway FBs. It can be performed with rigid or flexible bronchoscopes. Despite the preference for rigid bronchoscopy, flexible bronchoscopy is becoming increasingly important in the treatment of adult patients.

In the present study, we reviewed a series of adult patients submitted to flexible bronchoscopy as the first-choice method of removing airway FBs, in order to determine the success rate of the procedure.

\section{Methods}

This was a retrospective study. We reviewed the medical records of all adult patients who underwent bronchoscopy for airway FB removal between January of 2009 and January of 2011 in the Department of Respiratory Endoscopy of the University of São Paulo School of Medicine Hospital das Clínicas Heart Institute, located in the city of São Paulo, Brazil. The institutional review board of the hospital approved the study.

We collected data regarding the nature of the FB, the length of hospital stay, the location of the FB, the procedure used for FB removal, and complications.

All procedures were performed in the bronchoscopy room, equipped with anesthesia and cardiac arrest carts.
All of the patients were monitored by means of a cardioscope, a noninvasive blood pressure monitor, and a pulse oximeter. The patients were anesthetized with midazolam $(0.05 \mathrm{mg} /$ $\mathrm{kg})$, fentanyl $(1.0 \mathrm{\mu g} / \mathrm{kg})$, and propofol $(1.0 \mathrm{mg} /$ $\mathrm{kg})$. Topical anesthesia was performed with $1 \%$ lidocaine solution (maximum of $4.5 \mathrm{mg} / \mathrm{kg}$ ). Under direct vision into the airway through the working channel of a flexible bronchoscope (P30; Olympus BF, New Hyde Park, NY, USA), the airway was inspected and the FB was located. A flexible grasping forceps or a polypectomy snare was passed through the working channel, and attempts were made to grasp the FB and move it cranially.

During the procedure, the patients were under spontaneous ventilation. Occasional bleeding was controlled locally by topical instillation of a solution of cold saline and epinephrine ( $1: 20,000)$, if necessary.

In cases in which flexible bronchoscopy failed, the procedure was converted to rigid bronchoscopy (Karl Storz Instruments, Tuttlingen, Germany) with optical forceps (Hopkins ${ }^{\oplus}$; Karl Storz Instruments).

After the procedure, all of the patients were sent to a recovery room, being monitored and allowed to recover from anesthesia/sedation. Chest X-rays were taken in all of the cases in order to rule out pneumothorax.

\section{Results}

During the two-year study period, 40 adult patients underwent flexible bronchoscopy for FB removal. The mean age of the patients was 52 years (range, 18-88 years; Table 1). The median time of permanence of the FB in the airway was 15 days (range, $12 \mathrm{~h}$ to 10 years).

In 8 patients (20\%), the FBs (seven metallic objects and one peanut) were removed in less than $48 \mathrm{~h}$; in the remaining patients, the time of permanence of the FB was as follows: between $48 \mathrm{~h}$ and 30 days, in 18 (45\%); between 1 and 6 months, in $6(15 \%)$; between 6 months and 1 year, in 2 (5\%); and over 1 year, in 6 (15\%).

Chest X-rays were normal in 10 patients (25\%).

All of the 10 patients (25\%) with an FB in the airway for more than 3 months presented with abnormal chest $X$-rays, atelectasis being the most common finding (in 7 patients). Ironically, 3 patients presented with radiopaque $\mathrm{FB}$, hence the lack of suspicion. Those patients clinically 
presented with recurrent infections, chronic cough, or purulent sputum.

In regard to the nature of the $\mathrm{FB}, 25$ were inorganic, and 15 were organic. Metallic FBs accounted for 14 of the 25 inorganic FBs, and all were visible on chest $X$-rays. Of the 15 organic FBs, 8 were bones (chicken, pork, or fish), and none were radiologically visible. Only 6 of the 40 FBs (15\%) were seeds.

A history of choking was found in 21 patients (52.5\%). A fish bone was found in the larynx of 1 patient, dysphonia being the dominant symptom. Two FBs were found to be lodged in the trachea and caused severe dyspnea. In regard to side distribution, there were $26 \mathrm{FBs}$ in the right bronchial tree (4 in the middle lobe and 22 in the lower lobe) and 11 in the left bronchial tree ( 5 in the upper lobe and 6 in the lower lobe).

All of the patients were initially submitted to diagnostic flexible bronchoscopy, and, if the presence of an FB was confirmed, extraction was attempted in the same session. Extraction was successful in 33 patients (82.5\%). Six patients (15\%) required rigid bronchoscopy. Of those, 2 presented with tracheal FB aspiration (broken

Table $\mathbf{1}$ - Distribution of patients by age, foreign body (FB) type, FB location, and FB removal procedure.

\begin{tabular}{lc}
\hline \multicolumn{1}{c}{ Variable } & Patients, $\mathrm{n}(\%)$ \\
\hline Age, years & \\
$18-30$ & $5(20.0)$ \\
$31-40$ & $5(12.5)$ \\
$41-50$ & $8(20.0)$ \\
$51-60$ & $8(20.0)$ \\
$61-70$ & $6(15.0)$ \\
$>70$ & $5(12.5)$ \\
FB type & \\
Organic & $15(37.5)$ \\
lnorganic & $25(62.5)$ \\
Location & \\
Right bronchial tree & $26(65.0)$ \\
Middle lobe & $4(10.0)$ \\
Right lower lobe & $22(55.0)$ \\
Left bronchial tree & $11(27.5)$ \\
Left upper lobe & $5(12.5)$ \\
Left lower lobe & $6(15.0)$ \\
Trachea & $2(5.0)$ \\
Larynx & $1(2.5)$ \\
Procedure used for FB removal & \\
Flexible bronchoscopy & $33(82.5)$ \\
Rigid bronchoscopy & $6(15.0)$ \\
Bronchotomy & $1(2.5)$ \\
\hline
\end{tabular}

tracheostomy, in 1; and medical gauze, in 1) and were therefore unstable. In the remaining 4, the FBs were too large for safe removal with the flexible forceps. In addition, 1 patient had to undergo surgical bronchotomy after two unsuccessful attempts to retrieve a piercing impacted into the distal bronchial tree.

In 1 patient, a dental instrument (a tiny screwdriver; Figure 1) had been aspirated and was lodged into the distal tree of the right lower lobe (Figure 2). The instrument was not found during flexible bronchoscopy. Airway fluoroscopy was performed in order to guide the flexible forceps, and the FB was successfully removed.

After the procedure, all of the patients underwent chest X-rays. None of the patients presented with pneumothorax. During the procedure, the major complication was bleeding, which was managed by blood aspiration and instillation of the epinephrine solution, in 5 patients (12.5\%). In those patients, the time of permanence of the FB was over 3 months, causing granulation tissue formation around the FB. There were no complications after the procedure.

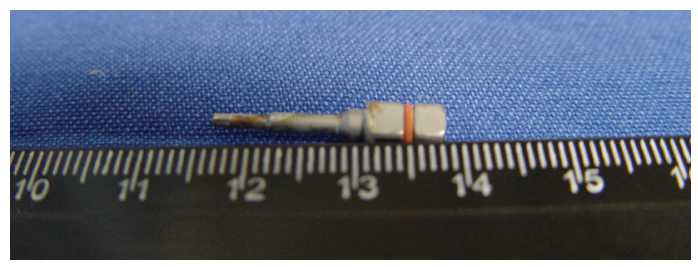

Figure 1 - A dental instrument (tiny screwdriver) removed from the right lower lobe of one of the patients.

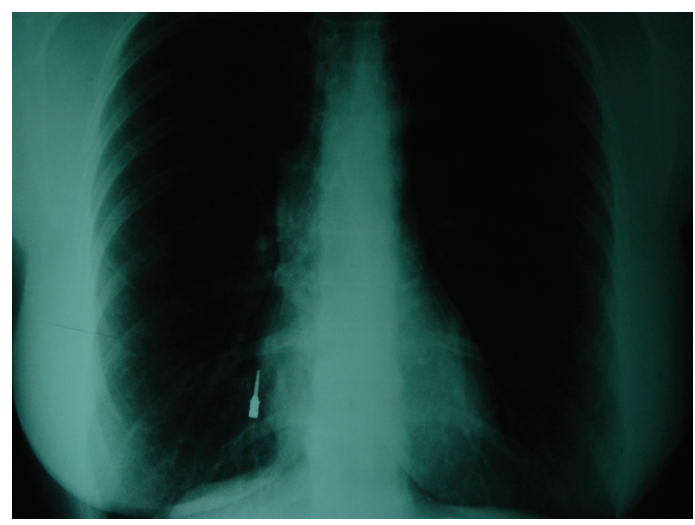

Figure $\mathbf{2}$ - Chest X-ray showing a foreign body (tiny screwdriver), which was removed with flexible bronchoscopy under fluoroscopic guidance. 


\section{Discussion}

In 1897, Gustav Killian performed the first bronchoscopy, in order to treat a patient with tracheal FB aspiration, extracting a pig bone using an esophagoscope. ${ }^{(4)}$ Since then, bronchoscopy has become common practice in the evaluation, diagnosis, and treatment of adults and children with FB aspiration. Before the 20th century, FB aspiration was associated with a high mortality rate (i.e., 24-50\%). ${ }^{(5,6)}$ Because FB removal was impossible then, the only treatment option was palliative tracheostomy, and patients had to cope with the complications related to the presence of an FB in the airway. With the development of bronchoscopy, the mortality rate associated with FB aspiration decreased to less than $1 \% .^{(6,7)}$

Regardless of the equipment used, bronchoscopy should be performed in all cases of suspected FB aspiration, even if the radiological findings are normal. ${ }^{(8,9)}$ In our series of patients, $25 \%$ of the chest X-ray findings were normal, despite a clinical history of FB aspiration.

Most of the literature on FB aspiration refers to statistics, diagnosis, and treatment in children younger than 16 years of age. Studies on FB aspiration in adults are scarce and involve patients in the 18-88 year age bracket (mean age, 60 years), ${ }^{(10)}$ which is consistent with the age range found in our study.

Adults seldom aspirate FBs. When this happens, the nature of the FB is highly variable, FB aspiration in adults being closely related to certain habits and professional activities. ${ }^{(11-13)}$ Dentures, nails, paper clips, and bone fragments are the most common FBs found in adults. Because of a combination of factors (including the use of small instruments and the fact that the patient is positioned with the neck extended and the mouth open, which results in an "unprotected airway"), dental procedures increase the chance of FB aspiration. Indeed, 5 patients (12.5\%) in our series presented with aspiration of tooth fragments and mini-drills.

The diagnosis of FB aspiration in adults is not a simple task. ${ }^{(14)}$ Patients do not always recollect a history of choking. In 6 of the 14 patients who had aspirated metallic FBs (visible on the chest X-rays), the diagnosis was delayed for more than 30 days, even in the younger patients. In addition, FB aspiration is often overlooked, except when the patient or a witness reports a typical episode of choking. In the literature, a history of choking has been reported in approximately $90 \%$ of the confirmed cases of FB aspiration in children, ${ }^{(15)}$ whereas, in our series, a history of choking was found in 21 patients (52.5\%).

The acute clinical presentation of the classic triad (coughing, wheezing, and diminished breath sounds) is unusual. In most cases, the aspirated FB migrates into the distal bronchial tree, ${ }^{(1)}$ and acute choking is self-limited and followed by a symptom-free period, which is misinterpreted as a sign of resolution, the diagnosis being therefore delayed. ${ }^{(2)}$ Our case series showed that 37 FBs $(92.5 \%)$ were lodged in the tracheobronchial tree. It is possible that this contributed to the long permanence of the FB in some patients.

When a large object is drawn into the airway, causing dyspnea, hoarseness, persistent cough, and cyanosis, the diagnosis of FB aspiration can be easily and quickly established. However, in adults, the caliber of the airway allows ventilation even in the presence of an $\mathrm{FB}$, subclinical presentation and normal physical examination being therefore common. When the diagnosis is delayed, the latency period between the episode of aspiration and the onset or worsening of the symptoms can last days, months, or even years, depending on the degree of airway obstruction and the nature of the aspirated FB (organic or inorganic).

The detection of a radiopaque FB is related to early diagnosis and treatment. Of the 8 FBs extracted in less than $48 \mathrm{~h}$ in our series, 7 were metallic objects, and 1 was an organic seed. In the presence of a normal chest X-ray, the clinical history becomes an important asset for the diagnosis.

Bronchoscopy remains the gold standard for the diagnosis and treatment of FB aspiration. $(3,16)$ Virtually all aspirated FBs can be extracted by bronchoscopy, with success rates above $98 \%$. Rigid bronchoscopy remains the standard procedure for the removal of $\mathrm{FBs}^{(9,17)}$ and has various advantages over flexible bronchoscopy. Rigid bronchoscopes are larger in diameter than are flexible bronchoscopes, therefore allowing blood aspiration, thick secretion aspiration, and patient ventilation.

In adults, diagnostic flexible bronchoscopy can be performed under conscious sedation. With the confirmation of FB aspiration, examination under general anesthesia and spontaneous ventilation facilitates the extraction of the object, as well as allowing rapid conversion to rigid bronchoscopy 
if necessary. Some authors have shown that even large FBs can be effectively and safely removed with a flexible bronchoscope. ${ }^{(18)}$

In the rare instances in which bronchoscopic removal fails, surgical bronchotomy or segmental resection is indicated. The presence of chronic bronchial obstruction, together with bronchiectasis, lung abscess, and parenchymal destruction, might be an indication for segmental or lobar resection. ${ }^{(19)}$

In our department, flexible bronchoscopy has been the procedure of choice for the diagnosis and treatment of FB aspiration in the adult population. In the last two years, FBs were successfully removed by flexible bronchoscopy in $82.5 \%$ of our patients, only 15\% of the patients having undergone rigid bronchoscopy. Therefore, our overall success rate was $97.5 \%$, there were no deaths, and only 1 patient (2.5\%) required surgery. A metallic piercing, which was no longer visible (not even with an ultrathin flexible bronchoscope), had been lodged in the airway of that patient for over 2 years. During the surgical procedure, it was noted that the FB had migrated to the lung parenchyma.

When an FB is visible on chest $\mathrm{X}$-rays but is lodged in the distal airway, FB removal with a flexible bronchoscope under direct vision is impossible, fluoroscopy being therefore needed in order to guide the grasping forceps. Airway fluoroscopy is safe and can be performed with a flexible bronchoscope or a rigid bronchoscope. In our series, only 1 patient, who had aspirated a dental instrument, required that procedure.

The removal of an FB can be performed with a flexible bronchoscope or a rigid bronchoscope. The bronchoscopist in charge of the procedure must be skilled and be familiar with the two modalities. The first attempt should be well planned, given that the number of unsuccessful attempts increases the risk of complications, such as swelling, bleeding, perforation, pneumothorax, and displacement into the central airways, which can be lethal. (2) After FB removal, the tracheobronchial tree should be carefully examined; if symptoms or abnormal X-ray findings persist, a new endoscopic procedure should be scheduled.

Many complications can occur after FB extraction, including laryngeal/pulmonary edema, hemoptysis, pneumothorax, tracheoesophageal fistula, pneumonia, atelectasis, fever, and respiratory failure. Complications might require prolonged hospitalization, including intensive care, intubation, mechanical ventilation, and additional bronchoscopic procedures. ${ }^{(18,20)}$

One must bear in mind that a patient undergoing therapeutic bronchoscopy can develop respiratory failure during the procedure. Whenever there is suspicion of FB aspiration, the procedure should be performed in a room equipped for resuscitation, mechanical ventilation, and rigid bronchoscopy. ${ }^{(21)}$

In the adult population, airway FBs can be removed safely and effectively with flexible bronchoscopy in many instances. However, it is imperative to note that rigid bronchoscopy remains the gold standard for the treatment of FB aspiration. Therefore, bronchoscopists treating patients with FB aspiration must be experts in rigid bronchoscopy, being assisted by skilled personnel and using appropriate equipment in the operating room or therapeutic endoscopy suite.

\section{References}

1. Qureshi A, Behzadi A. Foreign-body aspiration in an adult. Can J Surg. 2008;51(3):E69-70. PMid:18682760 PMCid:2496600.

2. Alvarez-Buylla Blanco M, Martínez Morán A, Alvarez Paredes 1, Martínez Vidal J. Bronchoscopy in children with foreign body aspiration [Article in Spanish]. Acta Otorrinolaringol Esp. 2008;59(4):183-9. PMid:18447977.

3. Tang FL, Chen MZ, Du ZL, Zou CC, Zhao YZ. Fibrobronchoscopic treatment of foreign body aspiration in children: an experience of 5 years in Hangzhou City, China. J Pediatr Surg. 2006;41(1):e1-5. PMid:16410080. http://dx.doi.org/10.1016/j.jpedsurg.2005.10.064

4. Zöllner F. Gustav Killian, father of bronchoscopy. Arch Otolaryngol. 1965;82(6):656-9. PMid:5321249.

5. Bittencourt PF, Camargos PA, Scheinmann P, de Blic J. Foreign body aspiration: clinical, radiological findings and factors associated with its late removal. Int $\mathrm{J}$ Pediatr Otorhinolaryngol. 2006;70(5):879-84. PMid:16280171. http://dx.doi.org/10.1016/j.ijporl.2005.09.024

6. Aytaç A, Yurdakul Y, lkizler C, Olga R, Saylam A. Inhalation of foreign bodies in children. Report of 500 cases. J Thorac Cardiovasc Surg. 1977;74(1):145-51. PMid:875433.

7. de Sousa ST, Ribeiro VS, de Menezes Filho JM, dos Santos AM, Barbieri MA, de Figueiredo Neto JA. Foreign body aspiration in children and adolescents: experience of a Brazilian referral center. J Bras Pneumol. 2009;35(7):653-9. PMid:19669003.

8. Orji FT, Akpeh JO. Tracheobronchial foreign body aspiration in children: how reliable are clinical and radiological signs in the diagnosis? Clin Otolaryngol. 2010;35(6):479-85. PMid:21199409. http://dx.doi. org/10.1111/j.1749-4486.2010.02214.x

9. Korlacki W, Korecka K, Dzielicki J. Foreign body aspiration in children: diagnostic and therapeutic role of bronchoscopy. Pediatr Surg lnt. 2011;27(8):833-7. PMid:21400033 PMCid:3136687. http://dx.doi. org/10.1007/s00383-011-2874-8 
10. Limper AH, Prakash UB. Tracheobronchial foreign bodies in adults. Ann Intern Med. 1990;112(8):604-9. PMid:2327678.

11. Karapolat S. Foreign-body aspiration in an adult. Can J Surg. 2008;51(5):411; author reply 411-2. PMid:18841225.

12. Ramos MB, Fernández-Villar A, Rivo JE, Leiro V, GarcíaFontán E, Botana Ml, et al. Extraction of airway foreign bodies in adults: experience from 1987-2008. Interact Cardiovasc Thorac Surg. 2009;9(3):402-5. PMid:19491125. http://dx.doi.org/10.1510/icvts.2009.207332

13. Mise K, Jurcev Savicevic A, Pavlov N, Jankovic S. Removal of tracheobronchial foreign bodies in adults using flexible bronchoscopy: experience 1995-2006. Surg Endosc. 2009;23(6):1360-4. PMid:18923871. http://dx.doi. org/10.1007/s00464-008-0181-9

14. Kogure Y, Oki M, Saka H. Endobronchial foreign body removed by rigid bronchoscopy after 39 years. Interact Cardiovasc Thorac Surg. 2010;11(6):866-8. PMid:20826558. http://dx.doi.org/10.1510/icvts.2010.243097

15. Kiyan G, Gocmen B, Tugtepe H, Karakoc F, Dagli E, Dagli TE. Foreign body aspiration in children: the value of diagnostic criteria. Int J Pediatr Otorhinolaryngol. 2009;73(7):963-7. PMid:19394092. http://dx.doi. org/10.1016/j.ijporl.2009.03.021

16. Shlizerman L, Mazzawi S, Rakover Y, Ashkenazi D. Foreign body aspiration in children: the effects of delayed diagnosis.
Am J Otolaryngol. 2010;31(5):320-4. PMid:20015771. http://dx.doi.org/10.1016/j.amjoto.2009.03.007

17. Grover S, Bansal A, Singhi SC. Airway foreign body aspiration. Indian J Pediatr. 2011;78(11):1401-3. PMid:21614604. http://dx.doi.org/10.1007/ s12098-011-0488-8

18. Boyd M, Chatterjee A, Chiles C, Chin R Jr. Tracheobronchial foreign body aspiration in adults. South Med J. 2009;102(2):171-4. PMid:19139679. http://dx.doi. org/10.1097/SMJ.0b013e318193c9c8

19. Isherwood J, Firmin R. Late presentation of foreign body aspiration requiring extracorporeal membrane oxygenation support for surgical management. Interact Cardiovasc Thorac Surg. 2011;12(4):631-2. PMid:21252207. http:// dx.doi.org/10.1510/icvts.2010.249516

20. Li Y, Wu W, Yang X, Li J. Treatment of 38 cases of foreign body aspiration in children causing lifethreatening complications. Int J Pediatr Otorhinolaryngol. 2009;73(12):1624-9. PMid:19733920. http://dx.doi. org/10.1016/j.ijporl.2009.08.003

21. Maddali MM, Mathew M, Chandwani J, Alsajwani MJ, Ganguly SS. Outcomes after rigid bronchoscopy in children with suspected or confirmed foreign body aspiration: a retrospective study. J Cardiothorac Vasc Anesth. 2011;25(6):1005-8. PMid:21474337. http:// dx.doi.org/10.1053/j.jvca.2011.02.005

\section{About the authors}

\section{Ascedio José Rodrigues}

Attending Physician. Department of Respiratory Endoscopy, Instituto do Coração - InCor, Heart Institute - University of São Paulo School of Medicine Hospital das Clínicas, São Paulo, Brazil.

\section{Eduardo Quintino Oliveira}

Attending Physician. Department of Respiratory Endoscopy, Instituto do Coração - InCor, Heart Institute - University of São Paulo School of Medicine Hospital das Clínicas, São Paulo, Brazil.

\section{Paulo Rogério Scordamaglio}

Attending Physician. Department of Respiratory Endoscopy, Instituto do Coração - InCor, Heart Institute - University of São Paulo School of Medicine Hospital das Clínicas, São Paulo, Brazil.

\section{Marcelo Gervilla Gregório}

Attending Physician. Department of Respiratory Endoscopy, Instituto do Coração - InCor, Heart Institute - University of São Paulo School of Medicine Hospital das Clínicas, São Paulo, Brazil.

\section{Márcia Jacomelli}

Attending Physician. Department of Respiratory Endoscopy, Instituto do Coração - InCor, Heart Institute - University of São Paulo School of Medicine Hospital das Clínicas, São Paulo, Brazil.

\section{Viviane Rossi Figueiredo}

Technical Director. Department of Respiratory Endoscopy, Instituto do Coração - InCor, Heart Institute - University of São Paulo School of Medicine Hospital das Clínicas, São Paulo, Brazil. 